\title{
RAINFALL INTERCEPTION BY SACRAMENTO'S URBAN FOREST
}

\author{
by Qingfu Xiao', E. Gregory McPherson², James R. Simpson², and Susan L. Ustin ${ }^{1}$
}

\begin{abstract}
A one-dimensional mass and energy balance model was developed to simulate rainfall interception in Sacramento County, California. The model describes tree interception processes: gross precipitation, leaf drip, stem flow, and evaporation. Kriging was used to extend existing meteorological point data over the region. Regional land use/ land cover and tree canopy cover were parameterized with data obtained by remote sensing and ground sampling. Annual interception was $1.1 \%$ for the entire county and $11.1 \%$ of precipitation falling on the urban forest canopy. Summer interception at the urban forest canopy level was $36 \%$ for an urban forest stand dominated by large, broadleaf evergreens and conifers (leaf area index $=6.1$ ) and $18 \%$ for a stand dominated by medium-sized conifers and broadleaf deciduous trees (leaf area index $=3.7$ ). For 5 precipitation events with return frequencies ranging from 2 to 200 years, interception was greatest for small storms and least for large storms. Because small storms are responsible for most pollutant washout, urban forests are likely to produce greater benefits through water quality protection than through flood control.
\end{abstract}

Keywords. Urban forest; rainfall interception; numerical modeling; Kriging; geographic information system; remote sensing; urban runoff

Cities across the United States are focusing stormwater management efforts on control of nonpoint source pollution and flooding. Development in upstream portions of watersheds is increasing flooding hazard to established downstream communities. Urban stormwater runoff is the second most common source of water pollution for lakes and estuaries and the third most common source for rivers nationwide (EPA 1994). During normal rainfall, pollutants are washed from impervious surfaces, lawns, and other sources into streams and storm sewerage systems (Claytor and Schueler 1996). During heavy rainfall, excessive runoff can outstrip the storage capacity of storm sewerage systems and streams. Localized flooding is a frequent result, and pollutant loading can exceed desirable levels at receiving water bodies and treatment plants. Also, heavy runoff increases soil erosion, as well as the transport and downstream deposition of pollutant-laden sediment.

A healthy urban forest can mitigate stormwater impacts of urban development (Sanders 1986; Lormand 1988). Trees intercept and store rainfall on leaves and branch surfaces, thereby reducing runoff volumes and delaying the onset of peak flows. Root growth and decomposition increase the capacity and rate of soils to infiltrate rainfall and reduce overland flow. Urban forest canopy cover reduces soil erosion by diminishing the impact of raindrops on barren surfaces. This study focuses on interception of rainfall by Sacramento's urban forest. Our objectives are to 1) quantify annual rainfall interception, 2) describe relations between interception and rainfall seasonality, duration, and volume for typical storm events, and 3 ) identify important structural traits of urban forests that can be manipulated to increase rainfall interception.

\section{Background}

Several studies have simulated urban forest impacts on stormwater runoff. Dayton, Ohio's, existing tree canopy cover ( $22 \%$ ) was found to lower potential runoff from a 6 -hour, 1-year storm by about $7 \%$ (Sanders 1986). By increasing tree cover to $50 \%$ over all pervious surfaces, runoff reduction was increased to $12 \%$. Five years of rainfall and runoff data were used to calibrate a simulation model for a small urban watershed in Tucson, Arizona. Increasing tree canopy cover from $21 \%$ (existing) to $35 \%$ and $50 \%$ was projected to reduce mean annual runoff by $2 \%$ and $4 \%$, respectively (Lormand 1988). These findings and more recent results (American Forests 1996) suggest that urban forest management can have a modest influence on runoff volume.

The simulation results reported above relied on application of models derived from TR-55 (Soil Conservation Service 1975). The TR-55 model and its adaptations are widely used to evaluate effects of land use change on runoff. However, they are limited in their capabilities to accurately estimate effects of urban forest management on runoff volume and peak rate. Some important limitations include the following.

1. Empirically derived runoff curve numbers are assigned for specific land or land cover types. Variations in the species composition and structure of urban forests within and among land use/ land cover types are not incorporated in the curve numbers. Therefore, impacts of selecting and locating different types of trees in alternative configurations cannot be evaluated.

2. Curve numbers were originally developed from 24-hour storm data and are assumed to be constant for a large range of rainfall events. Thus, 
TR-55 is better at predicting longer, larger storm events than smaller, shorter events (Pitt 1994). Because small storms are responsible for most annual urban runoff and pollutant washoff, accurate simulation of shorter events is important for water quality resource protection.

3. It is limited in computing the time of concentration and peak rates of flow for small catchments. This limits use of the model for flooding analysis.

4. Interception is held constant regardless of storm characteristics. Interception and depression storage (stormwater held in surface depressions) are modeled as storage capacities that are filled before overland flow begins. In fact, interception is a dynamic process, with canopy storage changing as water evaporates from the crown, drips from leaves, and flows down branches (Calder 1996).

Water quality is strongly related to water quantity or runoff. Canopy interception changes runoff quantity and the pollutant load from the canopy surfaces. Although hydrologic simulations using TR-55 and its adaptations have quantified effects of increasing and decreasing canopy cover on runoff, a better understanding of interception processes is needed to assist managers interested in managing urban forests for hydrologic benefits.

Forest canopy interception has been studied in both laboratory and field experiments (Rutter et al. 1971; Aston 1979; Gash et al. 1995). In rural forests, Zinke (1967) found that $15 \%$ to $40 \%$ of annual gross precipitation can be lost by interception in conifer-dominated forests and $10 \%$ to $20 \%$ in hardwood-dominated forests. Interception may exceed $59 \%$ for old growth forest trees (Baldwin 1938). However, information on interception by open-grown urban trees is lacking.

Statistical models estimate interception as a linear proportion of gross precipitation (Horton 1919; Zinke 1967). Regression coefficients for statistical methods are difficult to obtain because they are site specific and a long historical data record is needed to derive these coefficients. In contrast to the statistical approach, Rutter et al. $(1975,1977)$ developed a physically based canopy interception model that computes the water balance of canopy and trunk components. This approach was successfully tested (Gash and Morton 1978; Lloyd et al. 1988 ) with data from a coniferous plantation in Great Britain. Based on the assumption that the time lag between rainfall events was long enough for the canopy surface to dry, an analytical model was developed by Gash (1979) that has a simple form and is easier to apply than Rutter's model. Some other physically based interception models (Calder 1977; Gash et al. 1980;
Massman 1983) have been developed and applied to natural forests and found to produce results in agreement with field observed interception.

Forest-derived interception models may not be applicable to urban forests because both the microclimate and tree architecture of urban forests are different from those of rural forests. The gradient of microclimate can vary more quickly in urban forests than in rural forests. Microclimate differences affect evaporation rates, leaf drip, and other hydrologic processes in the tree crown. Compared with most rural forests, urban forests have fewer trees per unit area, tree size ( $\mathrm{dbh}$, diameter at breast height) that is larger on average, a more diverse mix of species with different phenological patterns, and greater spatial variation in canopy cover (McPherson 1998). Gash et al. (1995) found that existing interception models need to be reformulated for sparse forests.

In this study, a one-dimensional numerical model of rainfall interception was developed based on the previous work of Rutter et al. (1971) and Gash (1979). Rutter and Gash's model is physically based, and their parameters are easy to obtain. We used drying power of the air to estimate potential evaporation (Pruitt and Doorenbos 1977a, 1977b). Remotely sensed data and GIS techniques were used to characterize the land surface and link the model to specific local conditions.

Study site. Sacramento County is located in the lower Sacramento Valley of California and falls within the coordinates between longitudes W121 $51^{\prime} 43^{\prime \prime}$ and $W 121^{\circ} 01^{\prime} 20^{\prime \prime}$. For a more complete description of the study area and sampling units, see McPherson 1998 (pages 175-177 of this issue).

\section{Methodology}

The interception model. Gross precipitation is either intercepted by canopy leaves, branches, and trunk, or it falls directly to the ground without hitting the tree. Intercepted water is stored temporarily on canopy leaf and bark surfaces, eventually drips from leaf surfaces, and flows down tree stem surfaces to the ground, or it evaporates. Interception accounts for the sum of canopy surface water storage and evaporation. Interception loss accounts for the evaporation of water from canopy surfaces during the rainfall event and the evaporation of retained water on canopy surfaces after both canopy drip and stem flow cease. The total water balance on a canopy surface can be expressed by the following equation:

$$
\text { Interception }=C+E=P-T H-F-D
$$

where $C$ is the canopy surface water storage $(\mathrm{mm})$, which includes water storage on leaf and trunk surfaces); $E$ is evaporation from canopy surfaces $(\mathrm{mm})$, 
which includes evaporation from leaf, branches and trunk surfaces; $P$ is gross precipitation $(\mathrm{mm}) ; T H$ is free throughfall $(\mathrm{mm})$ (precipitation directly passing through the canopy); $F$ is stem flow $(\mathrm{mm})$; and $D$ is water drip from leaves and branches $(\mathrm{mm})$. For this interception model, gross precipitation $P$ was directly measured and the remaining variables were calculated from tree and climatic data. A detailed description and derivation of this model are presented in the appendix.

Model parameterization and scale up. We assumed that total rainfall interception is the summation of interception for all trees. Further, we assumed that leaf surface temperature is in equilibrium with air temperature and that leaf surface area is constant throughout the leaf-on (mid-March to mid-November) and leaf-off periods. At the smallest scale, interception was calculated for each cell in a grid system of length $d x$ $(100 \mathrm{~m}[330 \mathrm{ft}])$ and $d y(100 \mathrm{~m})$ that was superimposed on the study area. Interception was analyzed at 2 spatial scales: SubRADs (Sub-Regional Assessment Districts) and sectors. Interception values were aggregated for each of the 71 SubRADs and for each of the 3 sectors. Three groups of parameters were estimated.

Tree canopy characterization. Aerial photos and ground surveys were used to estimate tree species composition, tree dimensions, crown projection area (area enclosed by the dripline), and leaf surface area by SubRAD (see McPherson 1998, beginning on page 175 of this issue, for a detailed explanation of methods). Vegetation was divided into 3 categories: tree, shrub, and grass. Trees were further divided into broadleaf evergreen, broadleaf deciduous, conifer, and palm. Tree canopy parameters included species, leaf area (McPherson 1998), shade coefficient (visual density of the crown from McPherson 1984), and tree height. Three tree height classes were established: large ( $>15$ $\mathrm{m}[50 \mathrm{ft}]$ ), intermediate (5 to $15 \mathrm{~m}$ [ 16.5 to $50 \mathrm{ft}$ ]]), and small $(<5 \mathrm{~m})$. Tree height data were used to estimate wind speed at different heights above the ground and the resulting rates of evaporation (Jetten 1996). The volume of water stored in the tree crown was calculated from crown projection area (area under tree dripline), leaf area indexes (LAI, the ratio of leaf surface area to crown projection area), and water depth on the canopy surface. Species-specific shade coefficients influenced the amount of projected throughfall. Although rainfall is intercepted by trees, shrubs, and buildings, in this study we focused on rainfall interception by trees only.

Precipitation and potential evaporation. Scaling-up meteorological data from a limited number of stations to a region has been widely applied in hydrological and climatic studies (Hungerford et al. 1989;
Ustin et al. 1996; Xiao 1997). A Kriging method (Edward and Srivastava 1989) was used to extrapolate precipitation and evaporation data from a meteorological base station to the entire study area. Precipitation and evaporation coefficients of each grid cell were estimated as the ratio of the value at the cell to the value at the base station based on the spatial data extrapolation results from Kriging. The Stonemead base station ( $38^{\circ} 30^{\prime} 31^{\prime \prime} \mathrm{N}, 121^{\circ} 17^{\prime} 36^{\prime \prime} \mathrm{W}$, elevation $37 \mathrm{~m}$ [122 ft]) is located near the center of the study area and has been operated since 1982 by the California Department of Water Resources.

Meteorological parameters were derived based on data obtained from NOAA (National Oceanic and Atmospheric Administration), CIMIS (California Irrigation Management information System), and CDEC (California Data Exchange Center) meteorological stations located in or near the study area. Mean precipitation (from 57 stations) and evaporation (40 stations) data from stations with more than 20 years of meteorological records were used to create long-term averages for their respective grid cells. These data, in conjunction with Kriging, allowed us to conduct simulations for a variety of time intervals and weather conditions.

Numerical simulation. This study focused on the spatial and temporal distribution of canopy interception in Sacramento County. Three sets of simulations were conducted.

Annual interception. Data for a typical meteorological year (determined to be 1992 based on analysis of 10 years meteorological data at Stonemead station) were used to simulate annual canopy rainfall interception over the entire study area. Among the total 30 storms in 1992 at Stonemead, 7 storms had precipitation greater than $25.4 \mathrm{~mm}$ ( $1 \mathrm{in}$.), and these events accounted for $77 \%$ of total annual precipitation. Seven storms had precipitation between 6.2 and $25.4 \mathrm{~mm}(0.25$ to $1 \mathrm{in}$.), accounting for $17 \%$ of total annual precipitation. The remaining 16 events were each less than $6.2 \mathrm{~mm}$ and accounted for $6 \%$ of annual precipitation. We assumed that individual storms were separated by intervals of at least 24 hours without precipitation (Hamilton and Rowe 1949).

Summer and winter storm events. We simulated rainfall events occurring during summer (May 31, 1993) and winter (December 3, 1994) to examine effects of tree species composition and size on interception. The summer event depicted interception when deciduous trees were in-leaf, while the winter event occurred during the leaf-off season. Our analysis was limited to 2 adjacent SubRADs in the northern part of the county with very different forest structures. The rural SubRAD (Rio Linda-Elverta, $12.3 \mathrm{~km}^{2}\left[4.7 \mathrm{mi}^{2}\right]$ ) was dominated by relict native oaks and conifers $(68 \%$ of the trees 
were broadleaf evergreen and $17 \%$ coniferous). The city SubRAD (North Sacramento, $15.7 \mathrm{~km}^{2}$ [6 mi2]) contained a diverse mix of introduced shade trees and conifers characteristic of established neighborhoods near downtown Sacramento $(50 \%$ of the trees were broadleaf deciduous and $41 \%$ coniferous).

Flood events. Five additional storm events were selected to study interception for rainfall of different amounts and durations. Using the same two SubRADs as described above, we simulated precipitation events with return frequencies of $2,5,25,100$, and 200 years to better understand the extent to which Sacramento's urban forest can mitigate flooding. Rainfall events were selected from Stonemead's 1990 to 1997 records based on depth-duration-frequency relationships developed by the local flood control agency (City/County of Sacramento 1996). We simulated interception assuming both leaf-on and leaf-off conditions for deciduous trees for both the rural and city SubRAD sites.

Simulation results (annual, seasonal, and flood events) are presented at the urban forest canopy level and landscape level. Interception at the urban forest canopy level is the percentage of total precipitation falling on the urban forest canopy that is intercepted by the canopy $\left(\mathrm{mm}^{3}\right.$ interception per $\mathrm{mm}$ gross precipitation per $\mathrm{mm}^{2}$ crown projection area). Interception at the landscape level is the percentage of total precipitation falling on the entire study site that is intercepted by the urban forest canopy $\left(\mathrm{mm}^{3}\right.$ interception per $\mathrm{mm}$ gross precipitation per $\mathrm{mm}^{2}$ total land area).

To reduce numerical estimation errors, interception processes were simulated with an hourly time-step for analysis of annual interception and a 1-minute timestep for seasonal and flooding events. Due to the relatively small amount of stem surface area compared to leaf surface area (Vertessy et al. 1995) and low evaporation rate (Rutter and Morton 1977; Gash 1979), evaporation from stem surfaces was ignored by forcing the stem surface water storage capacity to zero.

\section{Results}

Annual interception. Annual rainfall interception by the tree canopy for the county averaged $1 \%$ at the landscape level and $11 \%$ at the urban forest canopy level for the 1992 meteorological year (Tables 1 and 2). At the landscape level, interception was greatest in the suburban sector, where leaf area index and canopy cover were greatest (Figure 1). Interception was least

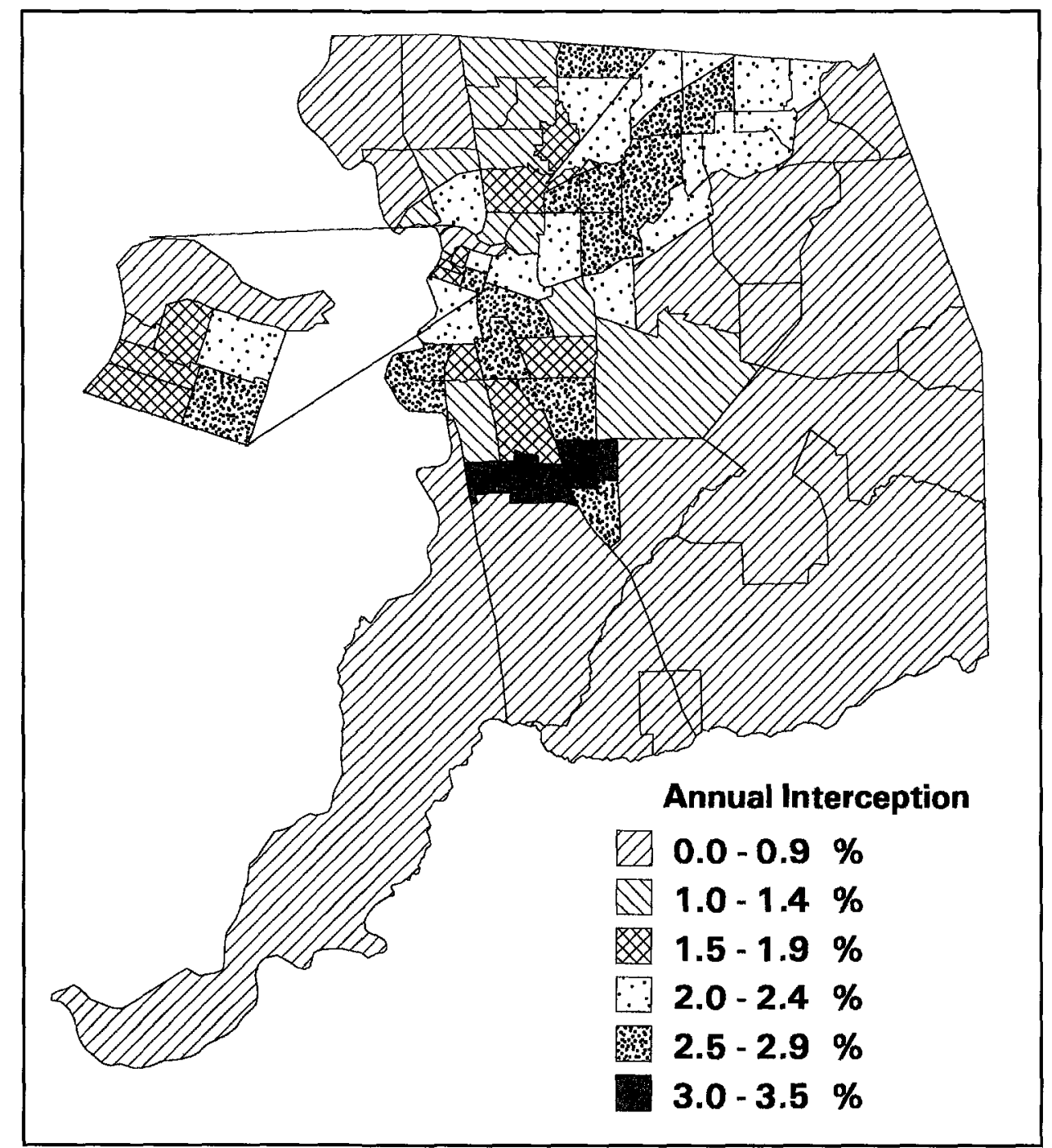

Figure 1. Spatial distribution of annual interception at landscape level; see equation 1. 
Table 1. Leaf area and canopy cover distribution.

\begin{tabular}{lrrrrrr} 
& & & & \multicolumn{3}{c}{ Leaf area $\left(\mathrm{km}^{2}\right)$} \\
\cline { 5 - 8 } Sector & Area $\left(\mathrm{km}^{2}\right)$ & Canopy & \multicolumn{1}{c}{$\mathrm{BE}^{\mathrm{a}}$} & \multicolumn{1}{c}{$\mathrm{BD}^{\mathrm{b}}$} & \multicolumn{1}{c}{ Conifer } & Palm \\
\hline City & 236.0 & $13.0 \%$ & 15.7 & 126.2 & 118.5 & 8.4 \\
Suburban & 371.4 & $15.4 \%$ & 239.4 & 182.7 & 182.9 & 7.9 \\
Rural & $1,970.9$ & $5.2 \%$ & 358.3 & 92.5 & 92.8 & 0.0 \\
County & $2,578.3$ & $7.4 \%$ & 613.4 & 401.4 & 394.2 & 16.3 \\
\hline
\end{tabular}

${ }^{a}$ Broadleaf evergreen

Broadleaf deciduous.

Table 2a. Annual rainfall interception at the urban forest canopy level $(\mathrm{mm})$, Sacramento County.

\begin{tabular}{llllll}
\hline Sector & $\begin{array}{l}\text { Gross } \\
\text { precipitation }\end{array}$ & Interception & $\begin{array}{l}\text { Free } \\
\text { throughfall }\end{array}$ & $\begin{array}{l}\text { Leaf } \\
\text { drip }\end{array}$ & $\begin{array}{l}\text { Stem } \\
\text { flow }\end{array}$ \\
\hline City & 393.2 & 23.5 & 266.3 & 101.0 & 2.5 \\
Suburban & 433.2 & 56.3 & 186.5 & 238.0 & 2.7 \\
Rural & 415.5 & 55.4 & 121.2 & 236.3 & 2.6 \\
County & 414.1 & 45.9 & 186.3 & 179.3 & 2.6 \\
\hline
\end{tabular}

Table $2 b$. Annual rainfall interception by percentage, Sacramento County.

\begin{tabular}{lll}
\hline Sector & $\begin{array}{l}\text { Landscape } \\
\text { level }\end{array}$ & $\begin{array}{l}\text { Urban forest } \\
\text { canopy level }\end{array}$ \\
\hline City & 1.8 & 6.0 \\
Suburban & 2.6 & 13.0 \\
Rural & 0.6 & 13.3 \\
County & 1.0 & 11.1 \\
\hline
\end{tabular}

in the rural sector due to its relatively low tree density, basal area, and canopy cover.

At the urban forest canopy level, interception was strongly influenced by the mix of tree species and their phenology. Interception was lowest in the city sector, where broadleaf deciduous trees dominated and were leafless during the winter rainy season (Table 1). In the suburban sector, broadleaf evergreens and conifer trees accounted for $67 \%$ of total leaf area. In addition to maintaining foliage year-round, evergreens generally have higher LAls than deciduous trees, thereby increasing canopy storage per unit crown projection area. Annual interception was as high as $22 \%$ for suburban SubRADs.

Summer and winter storm events. From the outset of the 6-hour, $12 \mathrm{~mm}$ (0.48 in.) summer storm (May $31,1993)$, canopy storage increased until saturated after about 2 hours in the city SubRAD and about 2.5 hours in the rural SubRAD (4 $\mathrm{mm}$ [0.16 in.]) (Figure 2). Maximum canopy storage in the rural SubRAD was nearly twice that of the city SubRAD ( 4.5 and $2.3 \mathrm{~mm}$ [0.18 and $0.09 \mathrm{in}$.). For the next 2 hours of relatively heavy rainfall, most precipitation reached the ground as leaf drip, throughfall, and stem flow. From hours 4 to 6 , the rainfall rate decreased and canopy storage gradually increased. After a continuously high leaf drip rate during hours 3 to 3.5 in the rural SubRAD, and

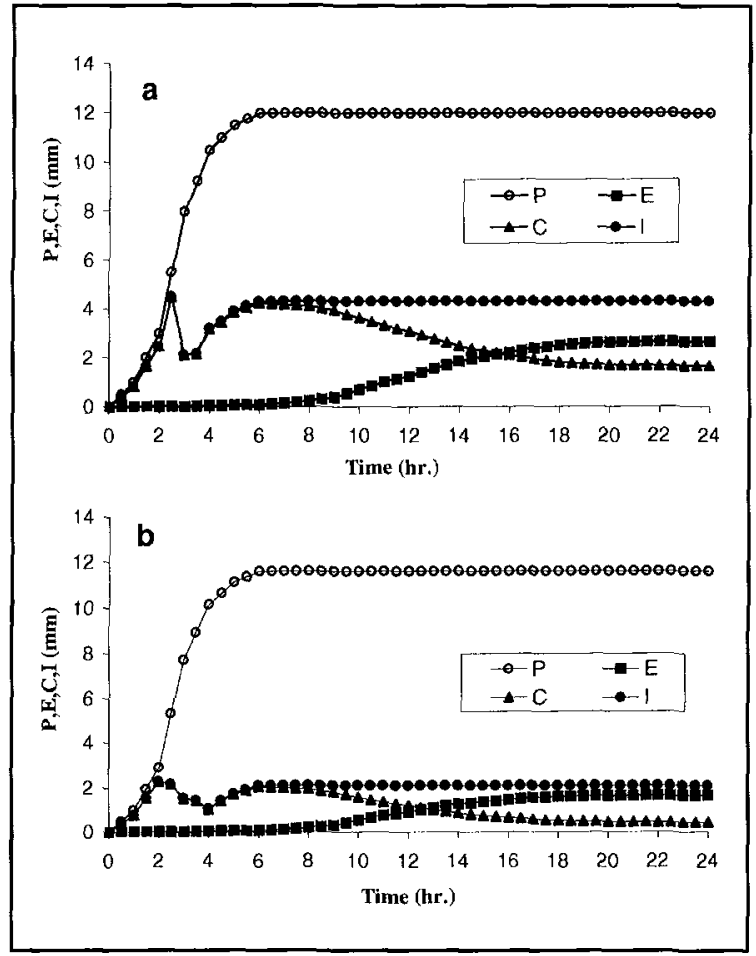

Figure 2. Distribution of rainfall interception in a rural SubRAD (a) and city SubRAD (b) during a summer storm (May 31, 1993). $P$ is gross precipitation, $E$ is evaporation, $C$ is canopy storage, and $I$ is canopy rainfall interception. $P, E, C$, and $I$ have units in $\mathrm{mm}$ of water.

hours 3.5 to 4 in the city SubRAD, canopy water storage was less than the maximum storage capacity. The small amount of rainfall added was not enough to fill canopy water storage to capacity. Once the rainfall stopped, canopy storage dropped and evaporation of intercepted rainfall began.

At the urban forest canopy level for the summer storm, interception loss was $36 \%$ and $18 \%$ for the rural and city SubRADs, respectively (Figure 2). Taller trees and more tree species with relatively high LAls in the rural than city SubRAD resulted in higher canopy storage and evaporation rates. More than $55 \%$ of trees in the rural SubRAD were large (tree height $>15 \mathrm{~m}$ [50 ft]) and the LAI was 6.1 , while more than $58 \%$ of the trees in the city SubRAD were medium size (height between 10 and $15 \mathrm{~m}$ [33 and $50 \mathrm{ft}$.] ) with LAls of 3.7 (Table 3).

The winter storm event (December 3, 1994) was much longer (44 hours) and larger (45 $\mathrm{mm}$ [1.78 in.]) than the summer event (Figure 3). Canopy storage steadily increased for about 6 hours, then declined once water began to drip off leaves and stems of 
Table 3. Leaf area distribution by tree type and height class (leat-on season).

\begin{tabular}{|c|c|c|}
\hline \multirow[b]{2}{*}{ Tree type/height class } & \multicolumn{2}{|c|}{ Leaf area ( $\%$ of total SubRAD) } \\
\hline & Rural SubRAD & City SubRAD \\
\hline \multicolumn{3}{|l|}{ Broadleaf deciduous } \\
\hline Large $^{a}$ & $5.7 \%$ & $27.2 \%$ \\
\hline Medium $^{b}$ & $9.5 \%$ & $21.4 \%$ \\
\hline Small $^{c}$ & $0.0 \%$ & $1.4 \%$ \\
\hline Subtotal & $15.2 \%$ & $50.0 \%$ \\
\hline \multicolumn{3}{|l|}{ Broadleaf evergreen } \\
\hline Large & $39.0 \%$ & $0.9 \%$ \\
\hline Medium & $29.1 \%$ & $2.0 \%$ \\
\hline Small & $0.1 \%$ & $1.7 \%$ \\
\hline Subtotal & $68.2 \%$ & $4.6 \%$ \\
\hline \multicolumn{3}{|l|}{ Conifer } \\
\hline Large & $10.3 \%$ & $7.4 \%$ \\
\hline Medium & $4.5 \%$ & $34.3 \%$ \\
\hline Small & $1.8 \%$ & $0.4 \%$ \\
\hline Subtotal & $16.6 \%$ & $42.1 \%$ \\
\hline \multicolumn{3}{|l|}{ Palm } \\
\hline Large & $0 \%$ & $1.7 \%$ \\
\hline Medium & $0 \%$ & $1.5 \%$ \\
\hline Small & $0 \%$ & $0.1 \%$ \\
\hline Subtotal & $0 \%$ & $3.3 \%$ \\
\hline Average LAI & 6.1 & 3.7 \\
\hline
\end{tabular}

Tree height greater than $15 \mathrm{~m}[50 \mathrm{ft}]$.

${ }^{b}$ Tree height 5 to $15 \mathrm{~m}[16.5$ to $50 \mathrm{ft}]$.

'Tree height less than $5 \mathrm{~m}[16.5 \mathrm{ft}]$.

saturated canopies. This pattern was repeated throughout the storm event as the canopy intercepted and lost rainfall in response to precipitation, leaf drip, and evaporation. It should be noted that evaporation rates were relatively low during the winter event. Compared to the summer event, air temperatures were cooler, relative humidity was higher, and net radiation was lower. Lower evaporation rates and lower LAI due to trees in a leaf-off condition (hence less canopy storage capacity) were primarily responsible for $14 \%$ (rural) to $26 \%$ (city) less interception during the winter event than the summer event.

At the urban forest canopy level, interception was $10 \%$ and $4 \%$, respectively, in the rural and city SubRADs. Broadleaf deciduous trees were leafless in December, which reduced LAls to 5.2 and 1.8, respectively, for the rural and city SubRADs. During winter, condensation sometimes occurs on plant surfaces from dew and fog. Higher LAls and more evergreen trees in the rural compared to city SubRAD account for increased fog trapping and interception.

Total canopy interception for the winter event in rural and city SubRADs was $4,212 \mathrm{~m}^{3}$ (3.41 acf) and $6,103 \mathrm{~m}^{3}$ (4.95 acf), respectively. This volume of water would increase detention storage of a $1 \mathrm{~km}^{2}(247$ ac) basin by a depth of $19 \mathrm{~mm}(0.75 \mathrm{in})$. Because tree crowns provide a type of detention storage, these results could be used as the basis for determining the economic value of canopy surface water storage.

Flood events. Canopy interception for 5 flooding events was greater for smaller, shorter storms than for larger and longer storm events (Table 4). During small events, a relatively large percentage of gross precipitation was required to fill canopy storage to capacity. Once storage was filled, relatively little precipitation was needed to maintain canopy saturation. Therefore, canopy interception had a minor impact on major flood events. For example, during the 200-year storm event, leaf-on interception loss was only $9 \%$ for the rural SubRAD and $5 \%$ for the city SubRAD (Table 4). In contrast, leaf-on interception was $37 \%$ and $20 \%$ for the 2 year event in the Rural and City SubRADs, respectively.

Differences between canopy interception for the leaf-on and leaf-off events reflected the impact of broadleaf evergreens and conifers in each SubRAD. Greatest interception loss occurred during the leaf-on season in both SubRADs. However, differences between leaf-off and leaf-on interception were greatest

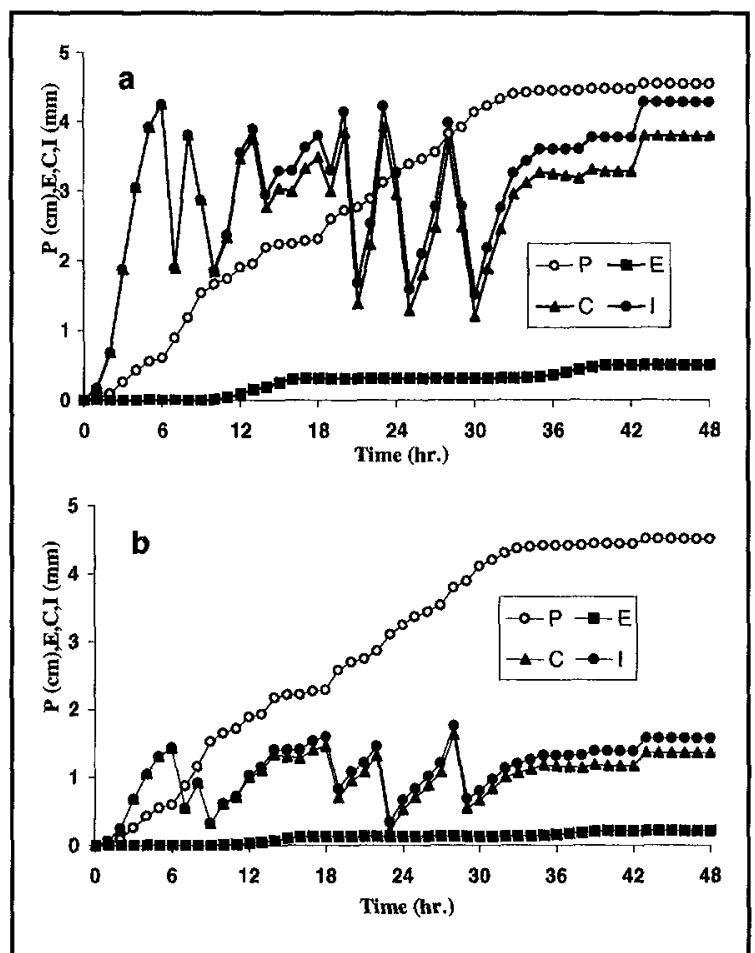

Figure 3. Temporal distribution of rainfall interception processes in a rural SubRAD (a) and city SubRAD (b) during a winter storm (December 3, 1994). $P$ is gross precipitation, $E$ is evaporation, $C$ is canopy storage, and $I$ is canopy rainfall interception. 
Table 4. Rainfall interception at the urban forest canopy level.

\begin{tabular}{|c|c|c|c|c|c|c|c|c|}
\hline \multicolumn{3}{|c|}{ Flood analysis events ${ }^{\mathrm{a}}$} & \multicolumn{2}{|c|}{ Actual precipitation } & \multicolumn{4}{|c|}{ Interception (\%) } \\
\hline \multirow[b]{2}{*}{ Year } & \multirow{2}{*}{$\begin{array}{l}\text { Amount/duration } \\
\text { (mm [hours]) }\end{array}$} & \multirow[b]{2}{*}{ Date } & \multirow{2}{*}{$\begin{array}{l}P^{b} \\
(\mathrm{~mm})\end{array}$} & \multirow{2}{*}{$\begin{array}{l}\text { Duration } \\
\text { (hours) }\end{array}$} & \multicolumn{2}{|c|}{ Rural SubRAD } & \multicolumn{2}{|c|}{ City SubRAD } \\
\hline & & & & & Leaf-off & Leaf-on & Leaf-off & Leaf-on \\
\hline 200 & $51.6[3]$ & Jan. 9,1995 & 64 & 5 & $7.4 \%$ & $8.7 \%$ & $2.4 \%$ & $4.9 \%$ \\
\hline 100 & $40.4[2]$ & Apr. $3,1996^{\circ}$ & 49 & 6 & $9.1 \%$ & $9.7 \%$ & $3.8 \%$ & $7.4 \%$ \\
\hline 25 & $32.0[2]$ & Jan. $10,1995^{\circ}$ & 32 & 3 & $9.6 \%$ & $11.0 \%$ & $5.7 \%$ & $8.9 \%$ \\
\hline 5 & $22.4[2]$ & Feb. 28, 1991 & 24 & 4 & $15.3 \%$ & $17.9 \%$ & $6.4 \%$ & $10.7 \%$ \\
\hline 2 & $11.4[1]$ & Feb. 18, 1996 & 15 & 2 & $32.8 \%$ & $36.9 \%$ & $9.9 \%$ & $19.7 \%$ \\
\hline
\end{tabular}

aFrom Sacramento County Drainage Manual 1997.

'Precipitation at base station.

'Storm occurs during leaf-on time.

$97 \%$ rainfall in first 2 hours.

in the city, where leaf-on loss was about $70 \%$ to $100 \%$ greater than leaf-off loss due to the relative abundance of broadleaf deciduous trees (Table 3). The large evergreen component in the rural SubRAD accounted for a smaller seasonal difference of about $20 \%$. As previously noted, greater overall leaf area in the rural versus city SubRAD was responsible for higher interception loss for all storm events.

Limitations of the model. This canopy interception model allows water to drip from leaves only after canopy storage exceeds saturated canopy storage. Because some leaf drip begins before canopy saturation, the model overestimates actual interception. During winter rainfall, water stored on stem surfaces is a large proportion of rainfall interception and temporary canopy water storage. By ignoring stem surface water storage, the model underestimates interception, especially for urban forest stands dominated by deciduous trees. In this study, only rainfall interception by trees is modeled. Shrubs and grasses also contribute to total interception. A full water budget includes contributions from all vegetation layers. This model has not been calibrated or validated with measured data from individual trees or an urban watershed. Thus, findings are approximations.

\section{Discussion and Conclusion}

Annual interception by the region's urban forest was $11.1 \%$ at the urban forest canopy level, close to reported values for hardwood forest stands. However, because of the region's relatively low tree density and the pattern of winter rainfall when deciduous trees are leafless, interception was only $1.1 \%$ at the county landscape level. At the landscape level, canopy interception reflected such structural attributes as tree density, basal area, and canopy cover. Increasing overall tree canopy cover will result in a direct increase in canopy interception.

At the urban forest canopy level, the mix of tree species and their size structures influenced intercep-

tion. In Sacramento, evergreen trees played the most important role in interception because most precipitation occurs in winter. Large trees with evergreen foliage contribute to greater interception than smaller, deciduous trees. In many climates with summer precipitation, deciduous trees make a substantial contribution to rainfall interception. Planting trees, as well as maintaining existing trees in a healthy condition, will reduce the volume of stormwater runoff over the long term.

These results indicate that urban forests become increasingly less effective at reducing stormwater runoff as the amount of precipitation per storm increases. Although trees reduce runoff, they may not be very effective for flood control. Floods usually occur during major storm events, well after canopy storage has been exceeded. However, by substantially reducing the amount of runoff during less extreme events, urban forests may protect water quality. Small storms, for which urban forest interception is greatest, are responsible for most annual pollutant washoff. Infrequently occurring large storms usually produce greatest flooding damage, and although they may contain significant pollutant loads, their contribution to the annual average pollutant load is quite small (Chang et al. 1990). Also, because of the infrequent occurrence of large storms, receiving waters have relatively long periods of recovery between events (Claytor and Schueler 1996). Therefore, urban forests are likely to produce more benefits through water quality protection than through flood control. Research is needed to better understand the interception process for opengrown urban trees, as well as the impacts of canopy interception on water quality.

\section{Literature Cited}

American Forests. 1996. Urban ecological analysis report, Phase 1: Economic benefits and costs of the urban forest in low income and non-low income communities. Final report NA-94-0297. American Forests, Washington, DC. 
Aston, A.R. 1979. Rainfall interception by eight small trees. J. Hydrol. 42:383-396.

Baldwin, J.I. 1938. Interception of snowfall by forests. New Hampshire For. \& Rec. Dept. Forest Notes 6 (mimeo).

Brutsaert, W. 1988. Evaporation into the AtmosphereTheory, History, and Applications. D. Reidel Publishing Company, Holland. 299 pp.

Calder, I.R. 1996. Rainfall interception and drop sizedevelopment and calibration of the two-layer stochastic interception model. Tree Physiol. 16:727-732.

Calder, I.R. 1977. A model of transpiration and interception loss from a spruce forest in Plynlimon, Central Wales. J. Hydrol. 33:247-265.

Chang, G., J. Parrish, and C. Souer. 1990. The first flush of runoff and its effect on control structure design. Environmental Resource Management Division. Department of Environmental and Conservation Services. City of Austin, Austin, TX. 36 pp.

City/County of Sacramento. 1996. Sacramento City/County Drainage Manual, Vol. 2, Hydrology Standards, Sacramento County Public Works Agency, Department of District Engineering, Water Resources Division, Sacramento, CA.

Claytor, R.A., and T.R. Schueler. 1996. Design of Stormwater Filtering Systems. The Center for Watershed Protection, Silver Spring, MD.

Dong, A., S.R. Grattan, J.J. Carroll, and C.R.K. Prashar. 1992. Estimation of daytime net radiation over well-watered grass. J. Irrig. Drain. Eng. 118(3):466-479.

Edward, H.I., and R.M. Srivastava. 1992. Applied Geostatistics. Oxford University Press, New York. 561 pp.

Environmental Protection Agency. 1994. The quality of our nation's water: 1992. United States Environmental Protect Agency, \#EPA-841-S-94-002. USEPA Office of Water, Washington, DC.

Gash, J.H.C., C.R. Lloyd, and G. Lachaud. 1995. Estimating sparse forest rainfall interception with an analytical model. J. Hydrol. 170:79-86.

Gash, J.H.C. 1979. An analytical model of rainfall interception by forests. Quart. J. R. Met. Soc. 105:43-55.

Gash, J.H.C., I.R. Wright, and C.R. Lloyd. 1980. Comparative estimates of interception loss from three coniferous forests in Great Britain. J. Hydrol. 48:89-105.

Gash, J.H.C., and A.J. Morton. 1978. An application of the Rutter model to the estimation of the interception loss from Thetford forest. J. Hydrol. 38:49-58.

Hamilton, E.L., and P.B. Rowe. 1949. Rainfall interception by chaparral in California. State of California, Dept. of Natural Resources, Division of Forestry. $43 \mathrm{pp}$.

Horton, R.E. 1919. Rainfall interception. Mon. Weather Rev. 47:603-623.

Hungerford, R.D., R.R. Nemani, S.W. Running, and J.C. Coughlan. 1989. MTCLIM: A mountain microclimate simulation model, Research paper INT-414. USDA For. Ser. Intermoun. Res. Sta., Ogden, UT.

Jetten, V.G. 1996. Interception of tropical rain forest performance of a canopy water balance model. Hydrol. Process. 10(5):671-685.

Lloyd, C.R., J.H.C. Gash, and W.J. Shuttleworth. 1988. The measurement and modeling of rainfall interception by Amazonian rain forest. Agric. For. Meteorol. 43:277-294.
Lormand, J.R. 1988. The effects of urban vegetation on strormwater runoff in an arid environment. Master's thesis, School of Renewable National Resources, Univ. Ariz., Tucson, AZ. 100 pp.

Massman, W.J. 1983. The derivation and validation of a new model for the interception of rainfall by forests. Agric. Meteorol. 28:261-286.

McPherson, E.G. 1998. Structure and sustainability of Sacramento's urban forest. J. Arboric. 24(4):174-190.

McPherson, E.G. 1984. Energy-Conserving Site Design. American Society of Landscape Architects, Washington, DC. $326 \mathrm{pp}$.

Monteith, J.L. 1973. Principles of Environmental Physics. American Elsevier Publ. Co., New York, NY. 241 pp.

Penman, K.L. 1948. Natural evaporation from open water, bare soil, and grass. Proc. Roy. Soc. London A198: $116-140$.

Pitt, R. 1994. Small storm hydrology. University of Alabama, Birmingham. Unpublished manuscript. Presented at Design of Stormwater Quality Management Practices, Madison, WI. May 17-19.

Pruitt, W.O., and J. Doorenbos. 1977a. Background and development of methods to predict reference crop evapotranspiration (ETO). Appendix II, 2nd edition, Crop Water Requirements, Irrigation and Drainage Paper No. 24. FAO, Rome, Italy, pp. 108-119.

Pruitt, W.O., and J. Doorenbos. 1977b. Empirical calibration, a requisite for evapotranspiration formulae based on daily or longer mean climate data. International Round Table Conference on "Evapotranspiration." Budapest, Hungary. Intl. Commission on Irrigation and Drainage. $20 \mathrm{pp}$.

Roland, B. Stull. 1988. An introduction to boundary layer meteorology. Kluwer Academic Publishers, Dordrecht, The Netherlands. $666 \mathrm{pp}$.

Rutter, A.J., A.J. Morton, and P.C. Robins. 1975. A predictive model of rainfall interception in forests, II. Generalization of the model and comparison with observations in some coniferous and hardwood stands. J. Appl. Ecol. 12:367-380.

Rutter, A.J., and A.J. Morton. 1977. A predictive model of rainfall interception in forests, III. Sensitivity of the model to stand parameters and meteorological variables. J. Appl. Ecol. 14:567-588.

Rutter, A.J., K.A. Kershaw, P.C. Robins, and A.J. Morton. 1971. A predictive model of rainfall interception in forests, 1. Derivation of the model from observations in a plantation of corsican pine. Agric. Meteorol. 9:367-384.

Sanders, $R$ A. 1986. Urban vegetation impacts on the hydrology of Dayton, Ohio. Urban Ecol. 9:361-376.

Soil Conservation Service. 1975. Technical Release No. 55. Urban hydrology for small watersheds. Soil Conservation Service, USDA, Washington, DC.

Ustin, S.L., W.W. Wallender, L. Costick, R. Lobato, S N. Martens, J. Pinzon, and Q.F. Xiao. 1996. Modeling terrestrial and aquatic ecosystem responses into Hydrologic Regime in a California watershed. In SNEP Science Team and Special Consultants (Eds.). Sierra Nevada Ecosystem Project final report to Congress: Status of the Sierra Nevada, Volume III: 275-307. Centers for Water and Wildland Resources, Univ. Calif., Davis, $C A$. 
Vertessy, R.A., R.G. Benyon, S.K. O'Sullivan, and P.R. Gribben. 1995. Relationships between stem diameter, sapwood area, leaf area and transpiration in a young mountain ash forest. Tree Physiol. 15:559-567.

Xiao, Q.F., S.L. Ustin, W.W. Wallander. 1996. A spatial and temporal continuous surface subsurface hydrological model. J. Geophys. Res., D, Atmos. 101 (D23):2956529584.

Zinke, P.J. 1967. Forest interception studies in the United States, pp 137-161. In Sopper, W.E., and Lull, H.W. (Eds.). Forest Hydrology. Pergamon Press, Oxford, England.

\section{Appendix: The Interception Model}

Precipitation water balance on a canopy surface can be expressed as:

$$
C=P-T H-F-D-E
$$

where $P$ is gross precipitation (above canopy), and $T H$ is free throughfall, which is the portion of precipitation that directly falls on the ground surface without hitting the canopy surface. $F$ and $D$ are stem flow and the water drip from canopy surface, and $E$ is evaporation from the canopy surface.

Differentiating equation (A1) with time gives the general canopy interception equation:

$$
\frac{d C}{d t}=p-t h-f-d-e
$$

where $p, t h, f, d$, and $e$ are the rate $(\mathrm{mm} / \mathrm{sec})$ of precipitation, throughfall, stem flow, canopy drip, and evaporation; $t$ is time (sec).

Interception $(D$ is the sum of canopy surface water storage $(C)$ and evaporation $(E)$. Interception loss $\left(L_{i}\right)$ accounts for all of the water evaporated from canopy leaf and branch surface (E).

Canopy drip rate is described as an exponential function of canopy storage and saturation storage capacity (Rutter et al. 1971; Lloyd et al. 1988; Jetten 1996):

$$
\begin{array}{ll}
d=0 & C<S \\
d=d_{0} e^{b(C-S)} & C \geq S
\end{array}
$$

where $S$ is the canopy surface saturation storage capacity $(\mathrm{mm}), d_{0}$ is the minimum drainage rate $(\mathrm{mm} / \mathrm{sec})$, which is the drainage rate when $C$ equals $S$, and $b$ is a dimensionless parameter.

To calculate drainage from stem surfaces (stem flow), we assume that water available on stem surfaces for drainage is supplied mainly by the proportion of the gross precipitation $\left(p_{s} p\right)$ and lost by both flow and evaporation. Evaporation from stem surface storage is small compared with evaporation from leaf surfaces. Rutter and Morton (1977) estimated it as $1 \%$ to $5 \%$ of the canopy evaporation value. Stem flow is calculated as directly proportional to precipitation $\left(q_{\text {stem }}=p_{s} p\right)$. Free throughfall is calculated as a fraction of gross precipitation $\left(t h=p_{f} p\right)$, where $p_{f}$ is the canopy shading coefficient.
Canopy evaporation is described as (Rutter et al. 1971):

$$
\begin{aligned}
& e=E_{p} \quad C \geq S \\
& e=E_{p} \frac{C}{S} \quad C<S
\end{aligned}
$$

where $E_{p}$ is potential evaporation rate $(\mathrm{mm} / \mathrm{sec})$ estimated using the Penman formula (Penman 1948):

$$
E_{p}=\frac{\Delta}{\Delta+\gamma} Q_{n e}+\frac{\gamma}{\Delta+\gamma} E_{A}
$$

where $\Delta$ is the rate of increase with temperature of the saturated water vapor pressure at air temperature, $\gamma$ is the psychometric constant $(\mathrm{Pa} / \mathrm{K})$. Net radiation $Q_{n o}$ $(\mathrm{mm} / \mathrm{sec})$ and drying power of the air $E_{A}(\mathrm{~mm} / \mathrm{sec})$ are defined as:

$$
\begin{aligned}
& Q_{n e}=c_{1} \frac{R_{n}}{L_{e}} \\
& E_{A}=c_{2} f_{e}\left(u_{r}\right)\left(e_{a}^{*}-e_{a}\right)
\end{aligned}
$$

where $R_{n}$ is net radiation $\left(\mathrm{W} / \mathrm{m}^{2}\right), L_{e}$ is latent heat of vaporization of water $(\mathrm{J} / \mathrm{kg}), e_{a}{ }^{*}$ and $e_{a}$ are saturation vapor pressure and vapor pressure at air temperature $(\mathrm{Pa})$, $c_{1}$ and $c_{2}$ are unit constants used to convert between $\mathrm{W} / \mathrm{m}^{2}$ and $\mathrm{mm} . f_{e}\left(u_{r}\right)$ is the wind function described as (Pruitt et al. 1977a, 1977b):

$$
f_{e}\left(u_{r}\right)=a_{u}+b_{u} u(z)
$$

where $a_{u}$ and $b_{u}$ are constants, and $u(z)$ is wind speed measured at height $z(\mathrm{~m} / \mathrm{sec})$.

In equation (A5), we use drying power of the air instead of aerodynamic resistance to calculate potential evaporation because the wind function (equation A8) is well studied in the study area (Pruitt et al. 1977a, 1977b). Simulation accuracy should increase due to the way evaporation is estimated.

Net radiation is calculated from solar radiation (Monteith 1973; Roland 1988; Dong et al. 1992). The wind profile at the meteorological station was retrieved from the wind speed measured at stand height (2 $\mathrm{m}[6.6 \mathrm{ft}$.] from ground surface) (Brutsaert 1988; Jetten 1996). We are not extrapolating air temperature and relative humidity from measurement height to actual canopy height because the vertical gradient is small.

Boundary and initial conditions must be determined before we can start solving these equations. Two flux boundaries are defined: upper boundary (at the canopy top) is determined by precipitation and evaporation rates, and lower boundary (at ground surface) is determined by canopy drainage (throughfali) and stem flow rates. To determine initial conditions, we assume that the canopy surface is dry before initiation of the precipitation event. 
The model (equation A1) is explicitly solved using finite differences. Numerical instability errors are reduced by limiting the maximum time step. Assuming air temperature and relative humidity measured from meteorological stations are representative of the canopy surface, these data can be used directly without modification.

Acknowledgements. We thank Drs. Bruce Ferguson (University of Georgia) and Eric Larsen (UC, Davis) for their comments on an earlier version of this manuscript. We appreciate Andrew Hertz for his assistance preparing canopy leaf and crown projection area calculations, Klaus Scott for help accessing and processing the meteorological data, James Goodridge (Division of Local Assistance, California Department of Water Resources) for providing Stonemead Station meteorological data, and Simon Eching (CIMIS program Development and Outreach, California Department of Water Resources) for his assistance using CIMIS data.

'Hydrologic Sciences, Dept. of Land, Air, and
Water Resources
University of California
Davis, CA 95616

${ }^{2}$ Pacific Southwest Research Station

USDA Forest Service

c/o Department of Environmental Horticulture

University of California

Davis, CA 95616

Résumé. L'interception de la pluie par la forêt urbaine a été étudiée dans le comté de Sacramento en Californie, une région où l'urbanisation est importante. En se basant sur la masse et sur la balance énergétique, un modèle similaire à celui de Rutter (1977) a été utilisé pour simuler l'interception de la pluie. Le modèle décrit les processus d'interception par les arbres à partir de données sur les quantités bruts et nets de précipitation, le ruissellement des feuilles, l'écoulement le long des tiges et l'évaporation. La méthodologie pour appliquer ce modèle unidimensionnel à un écosystème régional urbain est discutée. Une méthode particulière a été employée pour élargir à toute la région les données météorologiques recueillies à partir d'un point de mesure. Des techniques faisant appel aux systèmes d'information géographique (GIS) et à d'anciennes données de mesure ont été utilisées pour caractériser les utilisations locales du territoire et leur superficie. L'application de ce modèle à la forêt urbaine de Sacramento a permis de montrer que les pertes de précipitation par interception varient énormément selon la saison et la localisation. Au niveau du sol, la perte annuelle de précipitations suite à l'interception au niveau du couvert arboré a été évaluée à $1 \%$ dans la zone rurale et à $4 \%$ dans la zone urbaine. Au niveau de la cime des arbres, sous leur projection, les pertes annuelles suite à l'interception varient de $14 \%$ en zone urbaine à $17 \%$ en zone rurale. Lors d'une averse estivale - au niveau de la cime des arbres, sous leur projection $-42 \%$ des pertes en précipitations bruts sont dues à l'interception par le couvert arboré.

Zusammenfassung. Im Regierungsbezirk von Sacramento, CA, einer Region mit extensiver Besiedelung, wurde die Aufnahme von Niederschlägen durch einen urbanen Forst studiert. Basierend auf einer Massen- und Energiebilanz wurde ähnliches Modell wie Rutter (1977) genutzt, um die Niederschlagsaufnahme durch den Baum unter den Blattropfen, Stammabfluß und der Evaporation. Hier wird der methodische Ansatz für die Anwendung eines eindimensionalen Modells auf ein regionales, urbanes Ökosystem diskutiert. Die existierenden metereologischen Einzeldaten wurden auf die Region ausgedehnt. Um die Landnutzung und die Vegetationsdecke zu charakterisieren, wurde GIS (Geographisches Informationssystem) genutzt. Die Übertragung von diesem Modell auf die urbanen Forste von Sacramento zeigt, daß Verluste der aufgenommen Niederschläge stark swischen der Jahreszeit und der Örtlichkeit variieren. Im Bereich der Landschaft detrug der jährliche Niederschlagsverlust wegen der Aufnahme durch das Laubdach $1 \%$ in der Stadt und $4 \%$ auf dem Land. Auf der Projektionsebene der Baumkrone varooerte der jähijliche Aufnahmeverlust zwischen $14 \%$ in der Stadt und $17 \%$ auf dem Land. Während eines Sommeregens gingen $42 \%$ des Bruttoniederschlages infolge der Aufnahme durch die Baumkronen (auf dieser Projectionsebene) verloren.

Resumen. Se estudió la intercepción de la lluvia por un bosque urbano en el Condado de Sacramento, California, una región de urbanización extensiva. Se utilizó un modelo similar al de Rutter (1977), basado en balance de energía y masa, para simular la intercepció n de la lluvia. El modelo describe los procesos de intercepció $n$ de los árboles en aspectos de precipitació $\mathrm{n}$ total, precipitació n neta, goteo foliar, escurrimiento por el tronco y evaporació $n$. Se discute la metodología para aplicar este modelo unidimensional a un ecosistema urbano regional. Se usó Kriging para extender los datos meteorológicos puntuales a toda la región. Se utilizaron datos de sensorización remota y técnicas del Sistema de Información Geográfica (GIS) para caracterizar el uso regional de la tierra y la cobertura del terreno. La aplicación de este modelo al bosque urbano de Sacramento enseña que las pérdidas de intercepción de la lluvia varían fuertemente con la estación y la localidad. A nivel del paisaje la pérdida anual de precipitación debida a la intercepción foliar fue $1 \%$ en el sector Rural y $4 \%$ en el sector Ciudad. A nivel de la proyección de la copa de los árboles, las pérdidas anuales por intercepción variaron de $14 \%$ en el sector Ciudad a $17 \%$ en sector Rural. En un evento de lluvia de verano, $42 \%$ (a nivel de proyección de la copa) de la precipitación total se perdió debido a la intercepción de la copa. 